Article

\title{
Synthesis of Mg-Zn-Nd Master Alloy in Metallothermic Reduction of Neodymium from Fluoride-Chloride Melt
}

\author{
Ilia Beloglazov 1,*(D), Sergey Savchenkov ${ }^{2} \mathbb{D}$, Vladimir Bazhin ${ }^{3}$ and Rudolf Kawalla ${ }^{4}$ \\ 1 The Automation of Technological Processes and Production Department, Saint Petersburg Mining \\ University, 199106 Saint Petersburg, Russia \\ 2 Patent and Licensing Department, Saint-Petersburg Mining University, 199106 Saint Petersburg, Russia; \\ savchenkov_sa@pers.spmi.ru \\ 3 The Automation of Technological Processes and Production Department, Saint-Petersburg Mining \\ University, 199106 Saint Petersburg, Russia; bazhin_vyu@pers.spmi.ru \\ 4 Research of Technische Universität Bergakademie Freiberg, 09599 Freiberg, Germany; \\ Rudolf.Kawalla@imf.tu-freiberg.de \\ * Correspondence: beloglazov_ii@pers.spmi.ru; Tel.: +7-921-7785984
}

Received: 26 September 2020; Accepted: 29 October 2020; Published: 30 October 2020

check for updates

\begin{abstract}
In the presented article, a differential thermal analysis was carried out and the temperatures of thermal effects were established that arise during the reduction of neodymium from a technological salt mixture $\mathrm{KCl}-\mathrm{NaCl}-\mathrm{CaCl}_{2}-\mathrm{NdF}_{3}$ with a magnesium-zinc alloy. The results of experimental studies on the reduction of neodymium from a fluoride-chloride melt in a shaft electric furnace at temperatures of $550,600,650,700^{\circ} \mathrm{C}$ are presented. In order to increase the degree of extraction of neodymium into the $\mathrm{Mg}-\mathrm{Zn}-\mathrm{Nd}$ master alloy, the study of the influence of technological parameters on the degree of extraction of neodymium was carried out. It was experimentally proven that when zinc is added to a reducing agent (magnesium), the degree of extraction of neodymium into the master alloy is $99.5-99.7 \%$. The structure of the obtained master alloy samples, characterized by a uniform distribution of ternary intermetallic compounds $\left(\mathrm{Mg}_{3,4} \mathrm{NdZn}_{7}\right)$ in the volume of a double magnesium-zinc eutectic, was studied by optical and electron microscopy.
\end{abstract}

Keywords: magnesium-zinc-neodymium master alloy; Mg-Zn-Nd; magnesium master alloy; magnesium; rare-earth metals; master alloy synthesis; metallothermic reduction

\section{Introduction}

The addition of neodymium into the magnesium-zinc-zirconium system leads to a change in the phase composition of magnesium-based alloys. In this case, simultaneously with the known strengthening phases of magnesium with neodymium (for example, $\mathrm{Mg}_{12} \mathrm{Nd}$ ), phases of a more complex stoichiometric composition are formed, containing magnesium, neodymium, and zinc, for example $\mathrm{Nd}_{15} \mathrm{Mg}_{65} \mathrm{Zn}_{20}, \mathrm{Nd}_{16} \mathrm{Mg}_{37} \mathrm{Zn}_{47}, \mathrm{Nd}_{6} \mathrm{Mg}_{41} \mathrm{Zn}_{53}$ [1-7]. Due to the presence of these phases in the system, a combination of highly plastic and structural characteristics of magnesium alloys, as well as their high-temperature strength, is ensured, since the thermal expansion coefficient of long period stacking ordered (LPSO) phases is much lower than that of the basic $\alpha$-solid solution [8-11].

It is known that the production of magnesium and aluminum alloys is carried out by dissolving in the melt double and ternary master alloys, which are produced by fusing the components, using metallothermic reduction of alloying components from their compounds (for example, oxides or fluorides) or electrolysis [12-15]. In recent years, there has been a tendency to produce more complex 
master alloys, for example, ternary or quadruple [16-18]. It was found that ternary master alloys can be effectively used in the production of alloys based on light metals $[19,20]$.

In this regard, it seems relevant to develop new solutions for the production of complex magnesium master alloys including rare earth metals (REEs). It should be noted that for the domestic magnesium industry the task of obtaining magnesium alloys is of great importance in connection with the approval of the Strategy for the development of the metallurgical industry in Russia for the period up to 2030. In accordance with the sustainable development plan, the task of increasing the production of metallurgical products with high added value was approved, which should lead to a reduction in imports of such products [21]. In addition, the state's priority is to improve the quality of production of Russian metallurgical companies in order to increase the efficiency of processing mineral raw materials [22-29].

The aim of the work is to develop technological solutions that ensure high extraction of neodymium in the ternary $\mathrm{Mg}-\mathrm{Zn}-\mathrm{Nd}$ master alloy during metallothermic reduction of neodymium fluoride, which can be used in the production of high-strength and heat-resistant magnesium and aluminum alloys.

\section{Materials and Methods}

Differential thermal analysis (DTA) was carried out using a (NETZSCH, Selb, Germany) Simultaneous thermal analyzer (STA $429 \mathrm{CD}$ ) in a high purity argon flow at a gas flow rate of $50 \mathrm{~mL}$ per minute [30]. For the analysis, a salt mixture $35 \mathrm{KCl}-35 \mathrm{NaCl}-30 \mathrm{CaCl}_{2}-\mathrm{NdF}_{3}$, granular zinc and magnesium were weighed into an alundum melting pot. Two heating-cooling cycles were carried out at a rate of $10{ }^{\circ} \mathrm{C}$ per minute. In the first cycle, the melting pot with the weighed portion was heated to a temperature of $800{ }^{\circ} \mathrm{C}$, then cooled to $200{ }^{\circ} \mathrm{C}$; in the second successive cycle, the melting pot was heated from 200 to $800{ }^{\circ} \mathrm{C}$ and cooled again.

Experimental studies were carried out on a laboratory setup, which includes the following items: the shaft electric furnace with silicon carbide heating elements, the thermostat, the furnace control panel, the thermocouple and the stirring device. The synthesis of ternary master alloy $\mathrm{Mg}-\mathrm{Zn}-\mathrm{Nd}$ was carried out according to the following procedure. A mixture of salts consisting of Potassium chloride, ( $35 \mathrm{wt} . \%)$, Sodium chloride $(35 \mathrm{wt} . \%)$, Calcium chloride (30 wt.\%) was previously prepared. To this mixture was added neodymium fluoride $\left(\mathrm{NdF}_{3}\right)$ and the mixture stirred continuously. Then the resulting technological salt mixture was added to magnesium and zinc and placed in an alundum melting pot in the furnace. In the first series of experiments, in order to determine the optimal temperature condition for the synthesis of the master alloy, the melting pot was kept in a furnace with temperatures variations from 550 to $700{ }^{\circ} \mathrm{C}$, and the residence time from 15 to $30 \mathrm{~min}$, with a constant ratio of chlorides to neodymium fluoride. In the second series of experiments, in order to identify the most optimal technological condition, the synthesis temperature was varied from 650 to $700{ }^{\circ} \mathrm{C}$, the residence time from 20 to $30 \mathrm{~min}$, the ratio of chlorides to neodymium fluoride from 1:4 to 1:6. After the exposure time, in all experiments, the melt was settled for $5 \mathrm{~min}$. The surface part of the molten salt was poured out, and the resulting master alloy was poured into molds. The studies were carried out with a constant mass ratio of $\mathrm{Mg}: \mathrm{Zn} \mathrm{1:2}$ and components of the salt mixture $35 \mathrm{KCl}-35 \mathrm{NaCl}-30 \mathrm{CaCl}_{2}$, the qualifications of the initial salts of the mixture are: $\mathrm{KCl}, \mathrm{NaCl}, \mathrm{CaCl}_{2}$, - chemically pure, $\mathrm{NdF}_{3}$-pure. The average values of the degree extraction for neodymium obtained from the results of three parallel experiments are presented in the discussion of the results.

Elemental analysis of master alloy samples, which were obtained after DTA and experiments on a laboratory setup, was carried out on the sequential Wavelength Dispersive X-Ray Fluorescence Spectrometer XRF-1800 (Shimadzu, Kyoto, Japan). The metallographic study for the samples of the obtained master alloy was carried out on the Axiovert 40 MAT optical microscope (Carl Zeiss, Oberkochen, Germany) and the VEGA electron microscope (TESCAN, Brno, Czech Republic) with the INCAx-act energy dispersive spectrometer (Oxford Instruments, Abingdon, UK). The research 
was carried out with the involvement of the laboratory facilities of the Common Use Center of the Saint-Petersburg Mining University.

\section{Results}

At the first stage of experimental studies, DTA of the reduction process for neodymium from a technological salt mixture with a magnesium-zinc alloy was carried out. Figure 1 shows the thermograms obtained in the first heating cycle (green line of the curve) and the second heating cycle (purple line of the curve) of the $\mathrm{Mg}-\mathrm{Zn}-\mathrm{KCl}-\mathrm{NaCl}-\mathrm{CaCl}_{2}-\mathrm{NdF}_{3}$ sample up to $800{ }^{\circ} \mathrm{C}$.

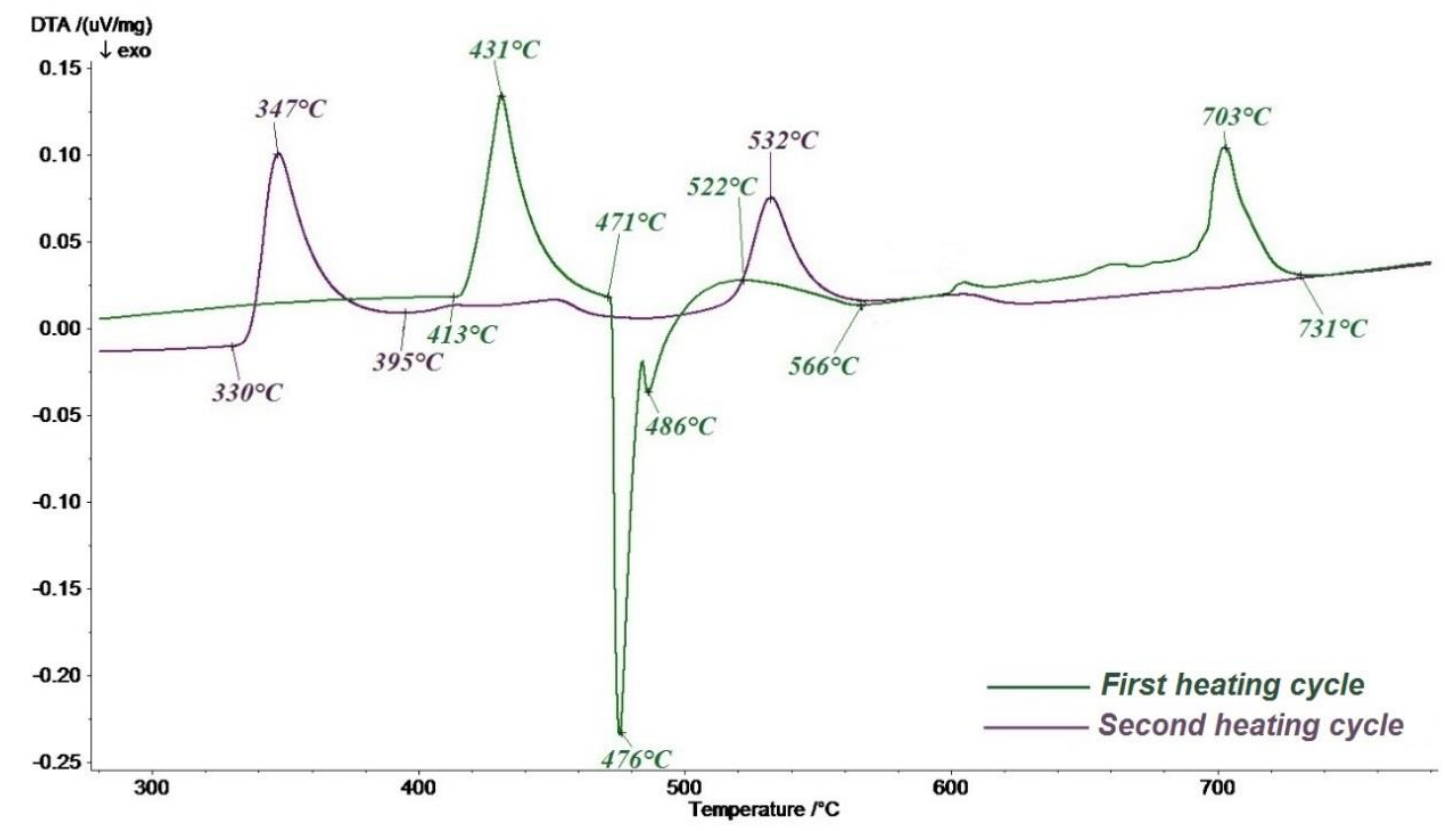

Figure 1. Thermograms of the first (green) and second (purple) heating cycle of the sample $\mathrm{Mg}-\mathrm{Zn}-\mathrm{KCl}-\mathrm{NaCl}-\mathrm{CaCl}_{2}-\mathrm{NdF}_{3}$ up to $800{ }^{\circ} \mathrm{C}$.

During the first cycle of heating the charge, the beginning of zinc melting was recorded at a temperature of $413{ }^{\circ} \mathrm{C}$. It was accompanied by an endothermic effect with a maximum at $431{ }^{\circ} \mathrm{C}$. The interaction with magnesium begins after the zinc melts, which is confirmed by a strong exothermic effect with a minimum at $476{ }^{\circ} \mathrm{C}$. It is typical for the process of formation of intermetallic compounds from pure elements. The exothermic peak with a minimum at $486^{\circ} \mathrm{C}$ cannot be interpreted since it is associated with the uneven melting of the charge and the peculiarity of filling the melting pot. The onset of the reduction of neodymium by magnesium-zinc melt from fluoride in the chloride melt was recorded at a temperature of $522^{\circ} \mathrm{C}$ after the end of the interaction of magnesium and zinc. This is confirmed by an extended exothermic effect with a minimum at $566^{\circ} \mathrm{C}$. The endothermic effect with a maximum at $703^{\circ} \mathrm{C}$ corresponds to the melting of the components of the technological salt mixture, and at the temperature of $731{ }^{\circ} \mathrm{C}$ all interactions in the system under study cease. During the second heating cycle, the thermogram recorded endothermic effects of melting of the magnesium-zinc alloy with a maximum at $347^{\circ} \mathrm{C}$ and a ternary master alloy with a maximum at $532^{\circ} \mathrm{C}$ It was found that this effect corresponds to the melting of a ternary compound $\mathrm{Mg}_{\mathrm{x}} \mathrm{Nd}_{\mathrm{y}} \mathrm{Zn}_{\mathrm{z}}$ [7].

Figure 2 shows the thermograms obtained in the first cooling cycle (blue line) and the second cooling cycle (brown line) of the $\mathrm{Mg}-\mathrm{Zn}-\mathrm{KCl}-\mathrm{NaCl}-\mathrm{CaCl}_{2}-\mathrm{NdF}_{3}$ sample up to $200{ }^{\circ} \mathrm{C}$. 


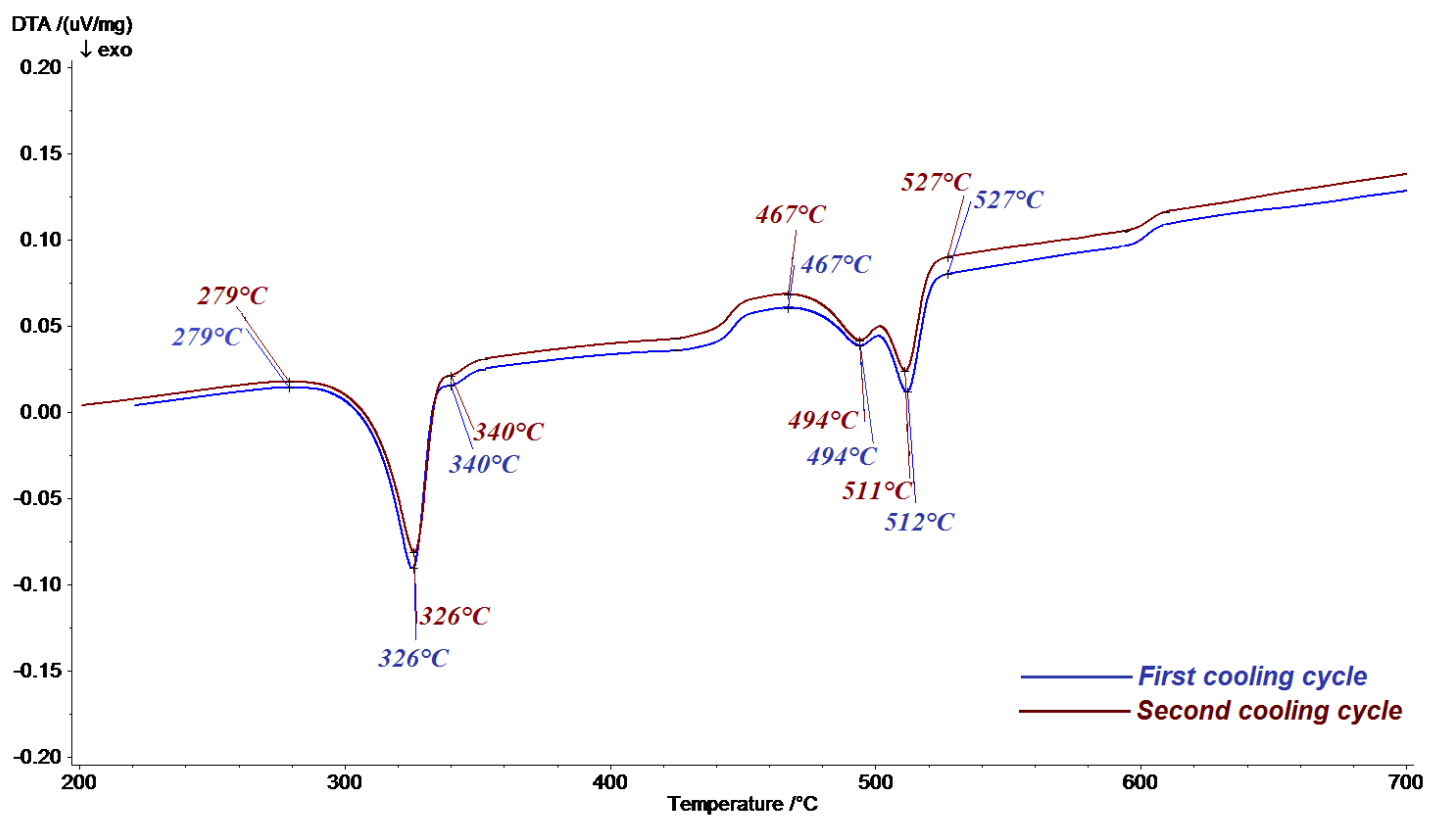

Figure 2. Thermograms of the first (blue) and second (brown) cooling cycle of the sample $\mathrm{Mg}-\mathrm{Zn}-\mathrm{KCl}-\mathrm{NaCl}-\mathrm{CaCl}_{2}-\mathrm{NdF}_{3}$ up to $200{ }^{\circ} \mathrm{C}$.

During the first and second cooling cycles, two thermal effects were revealed on the thermograms. The first with the minimum at $326^{\circ} \mathrm{C}$, corresponding to the crystallization of the double magnesium-zinc eutectic. The second at $511-512{ }^{\circ} \mathrm{C}$, corresponding to the crystallization of the $\mathrm{Mg}_{\mathrm{x}} \mathrm{Nd}_{\mathrm{y}} \mathrm{Zn}_{\mathrm{z}}$ ternary compound. In addition, thermal effects were recorded at the temperature of $494{ }^{\circ} \mathrm{C}$, corresponding to the crystallization of the reacted technological salt mixture. Elemental analysis of the obtained sample for the magnesium-zinc-neodymium master alloy showed the presence of $18.11 \mathrm{wt} . \%$ neodymium, which proves the fundamental possibility of obtaining the master alloy at temperatures up to $700{ }^{\circ} \mathrm{C}$ and indicates the process of the reduction of neodymium from the fluoride-chloride melt with the magnesium-zinc alloy (Table 1).

Table 1. Chemical composition of $\mathrm{Mg}-\mathrm{Zn}-\mathrm{Nd}$ master alloy.

\begin{tabular}{cccccccccc}
\hline & \multicolumn{8}{c}{ Mass Fraction, \% } \\
\cline { 2 - 9 } Master Alloy & \multicolumn{1}{c}{ Main Components } & \multicolumn{7}{c}{ Impurities } \\
\cline { 2 - 9 } & $\mathbf{Z n}$ & $\mathbf{M g}$ & $\mathbf{N d}$ & $\mathbf{F e}$ & $\mathbf{C u}$ & $\mathbf{N i}$ & $\mathbf{S i}$ & $\mathbf{A l}$ \\
\hline $\mathrm{Mg}-\mathrm{Zn}-\mathrm{Nd}$, & 53.46 & 28.15 & 18.11 & 0.12 & 0.06 & 0.01 & 0.05 & 0.04 \\
\hline
\end{tabular}

In the first series of experiments, the temperature effect on the degree of neodymium extraction was studied during experimental research on the neodymium reduction from a fluoride-chloride melt in a shaft electric furnace. In this case, in order to reduce the temperature for the synthesis of the ternary master alloy was taken the constant value of the Mg: $\mathrm{Zn}$ ratio equal to 1:2 [31]. As a result of processing the obtained data, the dependences of the degree of extraction of neodymium on the residence time at temperatures of $550,600,650,700{ }^{\circ} \mathrm{C}$ were assessed (Figure 3 ). 


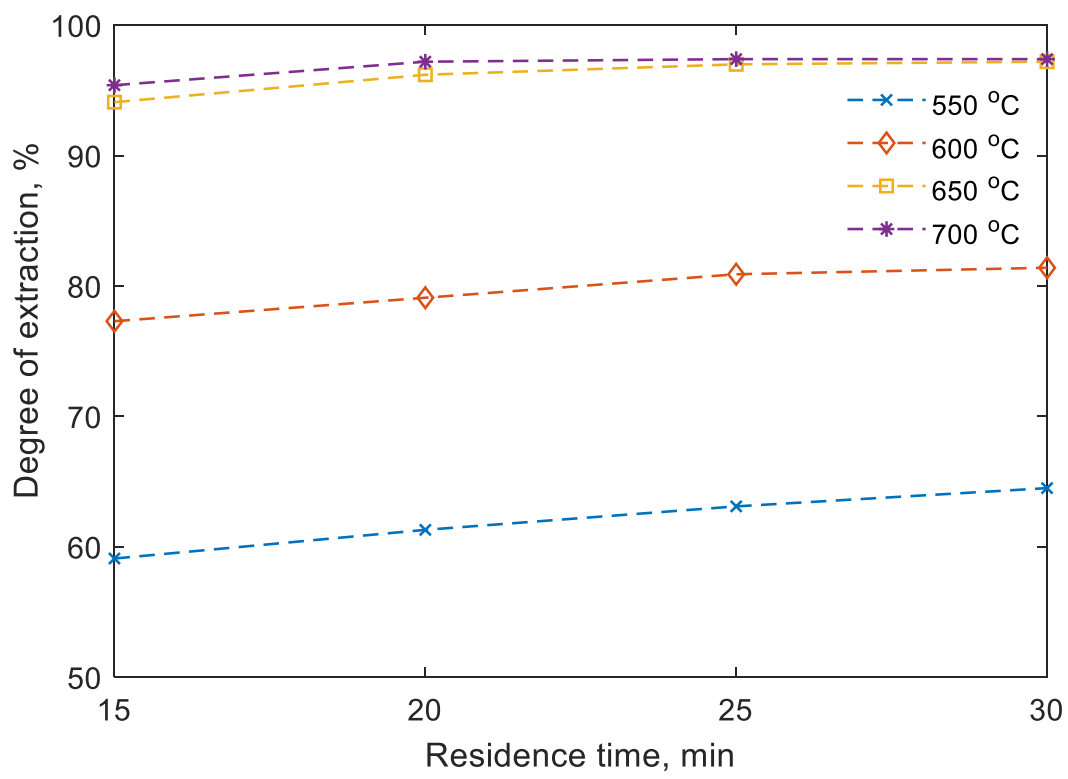

Figure 3. Dependence of the degree of extraction of neodymium and the residence time at temperatures of $550-700{ }^{\circ} \mathrm{C}$.

During the experiments, it was confirmed that the addition of zinc to the charge helps to reduce the temperature of the neodymium reduction process from the molten salt, in contrast to the temperature ranges for obtaining the double magnesium-neodymium master alloy [32]. It was found that the degree of extraction of neodymium of up to $60 \%$ is achieved at a synthesis temperature of $550{ }^{\circ} \mathrm{C}$. Moreover, the degree of extraction of neodymium increases to $92.2-93.2 \%$ with an increase in temperature to $650{ }^{\circ} \mathrm{C}$

In the second series of experiments, studies were carried out in order to identify the most optimal technological parameters for conducting melts. In this case, a high degree of neodymium extraction into the maser alloy is achieved. The initial data and the results of experiments on obtaining the master alloy are shown in Table 2.

Table 2. Results of synthesis of $\mathrm{Mg}-\mathrm{Zn}-\mathrm{Nd}$ master alloy.

\begin{tabular}{cccccc}
\hline Melt Number & Chloride Ratio: $\mathbf{N d F}_{\mathbf{3}}$ & $\mathbf{T}{ }^{\circ} \mathbf{C}$ & $\mathbf{t}, \mathbf{m i n}$ & Stirring & Nd Recovery, $\%$ \\
\hline 1 & $4: 1$ & 650 & 20 & no & 86.9 \\
2 & $6: 1$ & 650 & 20 & no & 95.8 \\
3 & $4: 1$ & 700 & 20 & yes & 88.1 \\
4 & $6: 1$ & 700 & 20 & yes & 99.6 \\
5 & $4: 1$ & 650 & 30 & yes & 88.4 \\
6 & $6: 1$ & 650 & 30 & yes & 99.5 \\
7 & $4: 1$ & 700 & 30 & no & 88.1 \\
8 & $6: 1$ & 700 & 30 & no & 96.3 \\
9 & $4: 1$ & 650 & 20 & yes & 86.2 \\
10 & $6: 1$ & 650 & 20 & yes & 99.6 \\
11 & $4: 1$ & 700 & 20 & no & 85.2 \\
12 & $6: 1$ & 700 & 20 & no & 91.4 \\
13 & $4: 1$ & 650 & 30 & no & 84.3 \\
14 & $6: 1$ & 650 & 30 & no & 93.6 \\
15 & $4: 1$ & 700 & 30 & yes & 87.9 \\
16 & $6: 1$ & 700 & 30 & yes & 99.6 \\
\hline
\end{tabular}

It was determined that the neodymium fluoride reduction is accompanied by the formation of the homogeneous magnesium-zinc-neodymium master alloy. According to experimental data, it has been 
proved that the neodymium yield increases to $99.6 \%$ with an increase in the ratio of chlorides to $\mathrm{NdF}_{3}$ up to $6: 1$ in the technological salt mixture and with continuous stirring of the melt. With an increase in temperature up to $700{ }^{\circ} \mathrm{C}$, the neodymium yield does not change significantly. As a result of the performed melts, master alloys with a neodymium content of 10 to $25 \mathrm{wt}$ \% were obtained. Analysis of the quality of the resulting master alloy showed that its macrostructure is characterized by the absence of gas pores and non-metallic inclusions (Figure 4).

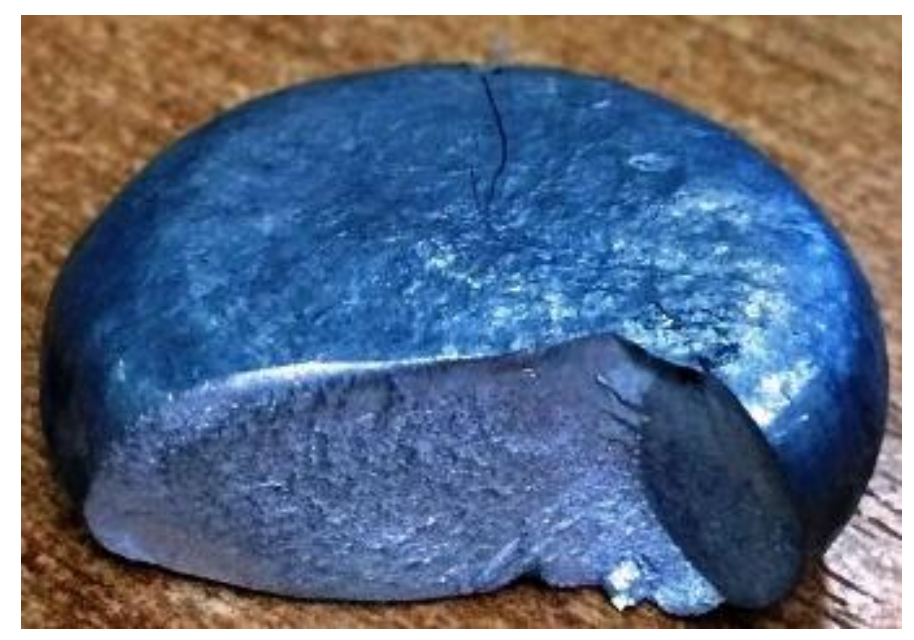

Figure 4. Macrostructure of master alloy $25 \mathrm{Mg}-50 \mathrm{Zn}-25 \mathrm{Nd}$.

Since there are no regulatory requirements for the ternary master alloy of the studied composition, the comparison was made with the requirements for the content of impurities for the magnesium-neodymium alloy; this one is also used for the production of special-purpose magnesium alloys. The $\mathrm{Mg}-\mathrm{Zn}-\mathrm{Nd}$ master alloys meets the requirements for $\mathrm{Mg}-\mathrm{Nd}$ magnesium master alloys according to specification TU 48-4-271-91 (Table 3).

Table 3. Chemical composition of $\mathrm{Mg}-\mathrm{Zn}-\mathrm{Nd}$ master alloy.

\begin{tabular}{cccccccccc}
\hline \multirow{2}{*}{ Alloy Grade } & \multicolumn{8}{c}{ Mass Traction, \% } \\
\cline { 2 - 9 } & \multicolumn{1}{c}{ Main Components } & \multicolumn{5}{c}{ Impurities, max } \\
\cline { 2 - 9 } & Zn & Mg & REEs & Fe & Cu & Ni & Si & Al \\
\hline MH & - & base & $20-35$ & 0.15 & 0.1 & 0.01 & 0.05 & 0.05 \\
Mg-Zn-Nd, melting №16 & base & 25.0 & 24.8 & 0.08 & 0.06 & - & 0.03 & 0.02 \\
\hline
\end{tabular}

The microstructure of all tested master alloys in the cast state consisted of a magnesium-zinc matrix, and well-distinguishable individual intermetallic compounds, mainly polygon-shaped. Regular shapes and some coagulation of the edges can be detected, which ultimately leads to the absence of local defects in the microstructure in the matrix. A significant part of the thin section for the obtained magnesium-zinc-neodymium master alloy with a content of $24.8 \mathrm{wt}$ \% neodymium (Figure 5a) is occupied by eutectic colonies (dark areas). It is located along the boundaries of the individual intermetallic compounds (light areas). In some cases, areas of accretion of intermetallic compounds are observed. The average grain diameter is $35 \mu \mathrm{m}$. Zones of eutectics are revealed at $\times 500$ magnification (Figure 5b). They are located within the individual intermetallic compounds. 


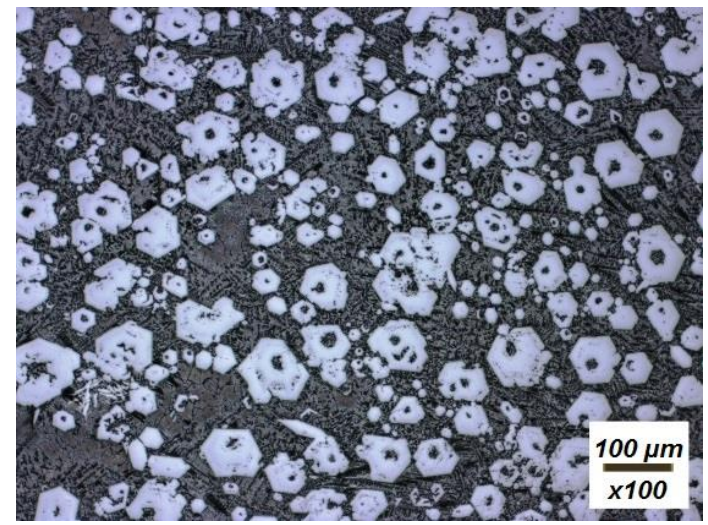

(a)

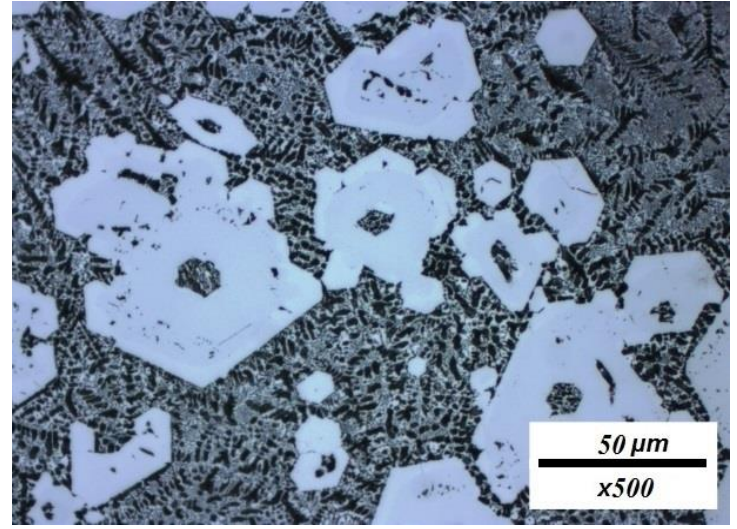

(b)

Figure 5. Microstructure of master alloy $25 \mathrm{Mg}-50 \mathrm{Zn}-25 \mathrm{Nd}$. Zoom $(\mathbf{a}) \times 100$, and $(\mathbf{b}) \times 500$.

Micro X-ray spectral analysis of the structure sections shows (Figure 6a) that individual intermetallic compounds contain about 21 wt.\% neodymium, which corresponds to the $\mathrm{Mg}_{3,4} \mathrm{NdZn}_{7}$ phase. Double eutectic (Figure 6b), alloyed with neodymium, contains 32.41 wt.\% magnesium, 60.72 wt.\% zinc and 6.88 wt.\% neodymium (Table 4 ).
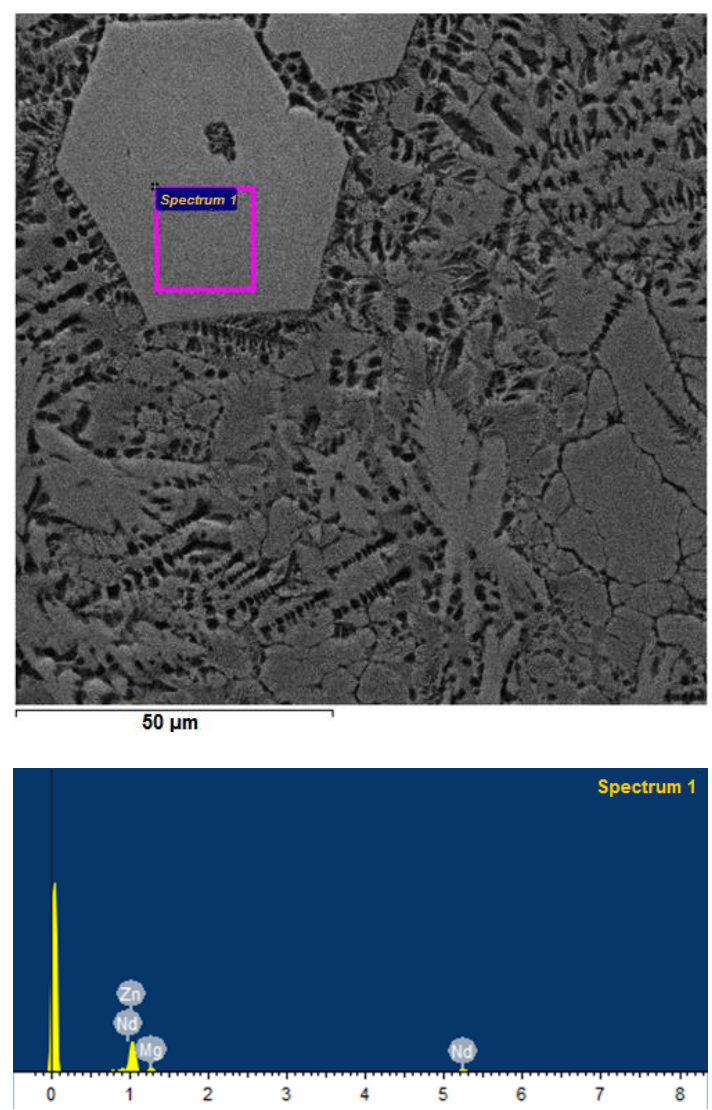

(a)
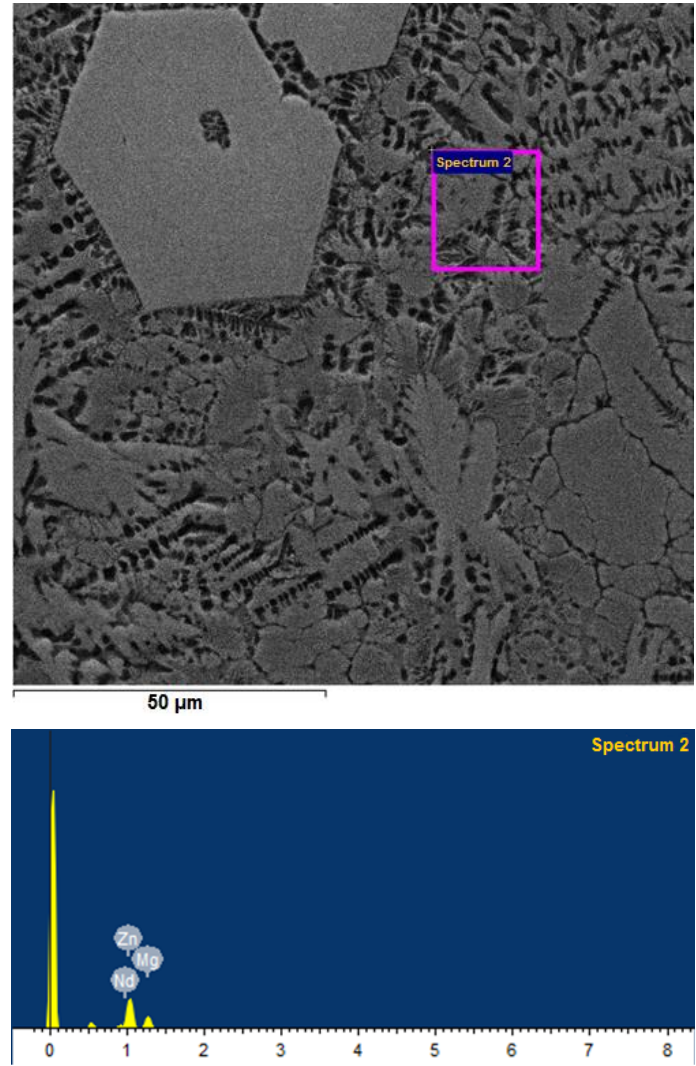

(b)

Figure 6. Electronic images of the microstructure of the $25 \mathrm{Mg}-50 \mathrm{Zn}-25 \mathrm{Nd}$ master alloy (a) and (b) $-\times 2000$. 
Table 4. Values of spectra of Mg-Zn-Nd master alloy.

\begin{tabular}{cccc}
\hline Spectrum & Mg, wt.\%. & Zn, wt.\%. & Nd, wt.\%. \\
\hline spectrum 1 (a) & 12.08 & 66.73 & 21.19 \\
spectrum 2 (b) & 32.41 & 60.72 & 6.88 \\
\hline
\end{tabular}

\section{Conclusions}

Thus, as a result of the experimental studies, a ternary master alloy of magnesium-zincneodymium was obtained, while optimal technological conditions of the synthesis were revealed (temperature $650^{\circ} \mathrm{C}$, residence time $20 \mathrm{~min}$, ratio of chlorides to neodymium fluoride 1:6, while stirring the melt), in this case, the degree of extraction of neodymium achieved is up to $99.6 \%$.

It was established that the onset of the reduction of neodymium by magnesium-zinc melt from its fluoride in the chloride melt occurs at a temperature of $522^{\circ} \mathrm{C}$ using DTA. This is confirmed by an extended exothermic effect with a minimum at $566^{\circ} \mathrm{C}$.

Analysis of the microstructure showed that the obtained ternary master alloy $25 \mathrm{Mg}-50 \mathrm{Zn}-25 \mathrm{Nd}$ is characterized by a uniform distribution of intermetallic compounds $\left(\mathrm{Mg}_{3} \mathrm{NdZn}_{6}\right)$ in the bulk of the double magnesium-zinc eutectic. The obtained experimental data are a prerequisite for the development of industrial technology for the production of magnesium-zinc-neodymium alloys for their use in non-ferrous and ferrous metallurgy.

Author Contributions: Conceptualization, I.B.; methodology, S.S.; software, I.B.; validation, S.S., I.B., R.K.; formal analysis, V.B.; investigation, I B.; resources, S.S.; writing-original draft preparation, S.S.; writing-review and editing, R.K. and V.B.; visualization, I.B.; supervision, R.K.; project administration, I.B.; funding acquisition, I.B. All authors have read and agreed to the published version of the manuscript.

Funding: This research received no external funding.

Acknowledgments: The authors thank St. Petersburg Mining University for the opportunity to realize research. The studies were performed using the equipment of the Common Use Centre of the Saint-Petersburg Mining University.

Conflicts of Interest: The authors declare no conflict of interest.

\section{References}

1. Solomon, E.L.S.; Araullo-Peters, V.; Allison, J.E.; Marquis, E.A. Early precipitate morphologies in $\mathrm{Mg}-\mathrm{Nd}-(\mathrm{Zr})$ alloys. Scr. Mater. 2017, 128, 14-17. [CrossRef]

2. Chen, J.K.; Chen, Y.C.; Hsien-Tsung, L.I.; Chan, K.S.; Chang, C.J. Effects of Nd and rotary forging on mechanical properties of AZ71 Mg alloys. Trans. Nonferrous. Met. Soc. China 2015, 25, 3223-3231. [CrossRef]

3. Zhou, B.; Wang, L.; Chen, B.; Jia, Y.; Wen, W.; Li, D.; Shu, D.; Jin, P.; Zeng, X.; Ding, W. Study of age hardening in a Mg-2.2 Nd alloy by in situ synchrotron X-ray diffraction and mechanical tests. Mater. Sci. Eng. 2017, 708, 319-328. [CrossRef]

4. Jin, S.; Zhang, D.; Lu, X.; Zhang, Y.; Tan, L.; Liu, Y.; Wang, Q. Mechanical properties, biodegradability and cytocompatibility of biodegradable Mg-Zn-Zr-Nd/Y alloys. J. Mater. Sci. Technol. 2020, 47, 190-201. [CrossRef]

5. Wang, W.; Wu, D.; Chen, R.; Qi, Y.; Ye, H.; Yang, Z.Q. Revisiting the role of Zr micro-alloying in a Mg-Nd-Zn alloy. J. Alloy Compd. 2020, 832, 155016. [CrossRef]

6. Sheng, L.; Du, B.; Hu, Z.; Qiao, Y.; Xiao, Z.; Wang, B.; Xu, D.; Zheng, Y.; Xi, T. Effects of annealing treatment on microstructure and tensile behavior of the Mg-Zn-Y-Nd alloy. J. Magnes. Alloy 2020, 8, 601-613. [CrossRef]

7. Zhu, Z.; Gharghouri, M.A.; Pelton, A.D. Thermodynamic modelling and in-situ neutron diffraction investigation of the (Nd+Mg+Zn) system. J. Chem. Thermodyn. 2016, 94, 43-51. [CrossRef]

8. Li, Z.; Liu, F.; Yuan, A.; Duan, B.; Li, Y.; Li, X. Effect of rolling deformation on microstructure and texture of spray-deposited magnesium alloy containing Mg-Nd-Zn typed LPSO. J. Mater. Sci. Technol. 2017, 33, 630-636. [CrossRef] 
9. Peng, Y.-G.; Du, Z.-W.; Liu, W.; Li, Y.-J.; Li, T.; Han, X.-L.; Ma, M.-L.; Pang, Z.; Yuan, J.-W.; Shi, G.-L. Evolution of precipitates in $\mathrm{Mg}-7 \mathrm{Gd}-3 \mathrm{Y}-1 \mathrm{Nd}-1 \mathrm{Zn}-0.5 \mathrm{Zr}$ alloy with fine plate-like $14 \mathrm{H}-\mathrm{LPSO}$ structures aged at $240{ }^{\circ} \mathrm{C}$. Trans. Nonferrous Met. Soc. China 2020, 30, 1500-1510. [CrossRef]

10. Yu, Z.; Xu, C.; Meng, J.; Zhang, X.; Kamado, S. Microstructure evolution and mechanical properties of as-extruded Mg-Gd-Y-Zr alloy with Zn and Nd additions. Mater. Sci. Eng. A 2018, 713, 234-243. [CrossRef]

11. Lan, A.; Huo, L. Effect of substitution of minor Nd for $\mathrm{Y}$ on mechanical and damping properties of heat-treated Mg-Zn-Y-Zr alloy. Mater. Sci. Eng. A 2016, 651, 646-656. [CrossRef]

12. Guobing, W.; Xiaodong, P.; Junchen, L.; Weidong, X.; Qunyi, W. Structure Heredity Effect of Mg-10Y Master Alloy in AZ31 Magnesium Alloy. Rare Met. Mater. Eng. 2013, 42, 2009-2013. [CrossRef]

13. Khrustalyov, A.P.; Garkushin, G.V.; Zhukov, I.A.; Razorenov, S.V.; Vorozhtsov, A.B. Quasi-Static and Plate Impact Loading of Cast Magnesium Alloy ML5 Reinforced with Aluminum Nitride Nanoparticles. Metals 2019, 9, 715. [CrossRef]

14. Kaminsky, V.V.; Petrovich, S.A.; Lipin, V.A. Production of intermetallides in the Al-Ti-Zn system. J. Min. Inst. 2018, 233, 512-517.

15. Glavatskikh, M.V.; Pozdnyakov, A.V.; Makhov, S.V.; Napalkov, V.I. Investigation into the structure and phase composition of powder aluminum-phosphorus master alloys. Russ. J. Nonferrous Met. 2014, 55, 450-455. [CrossRef]

16. Xiaodong, P.; Junchen, L.; Sunyun, X.; Guobin, W.; Yan, Y. Effects of Different State Mg-5Sr-10Y Master Alloys on the Microstructure Refinement of AZ31 Magnesium Alloy. Rare Met. Mater. Eng. 2013, 42, 2421-2426. [CrossRef]

17. Savchenkov, S.A.; Bazhin, V.Y.; Povarov, V.G. Research on the process of gadolinium recovery from the melt of salts on formation of $\mathrm{Mg}-\mathrm{Zn}-\mathrm{Gd}$ master alloys for manufacturing of magnesium and aluminium special-purpose alloys. Nonferrous Met. 2020, 48, 35-40.

18. Zhang, Y.; Ye, C.; Shen, Y.; Chang, W.; StJohn, D.; Wang, G.; Zhai, Q. Grain refinement of hypoeutectic Al-7wt.\%Si alloy induced by an Al-V-B master alloy. J. Alloy Compd. 2020, 812, 152022. [CrossRef]

19. Jiang, Z.; Meng, X.; Jiang, B.; Jiang, S.; Dai, J.; Dong, J.; Ding, Y. Grain refinement of Mg-3Y alloy using $\mathrm{Mg}-10 \mathrm{Al} 2 \mathrm{Y}$ master alloy. J. Rare Earths 2020, in press. [CrossRef]

20. Xiaoyan, W.; Zhang, H.; Feng, J.; Ying, Y.; Lina, J.; Hu, Z. Microstructure and Grain Refinement Performance of a New Al-5Nb-RE-B Master Alloy. Rare Met. Mater. Eng. 2018, 47, 2017-2022. [CrossRef]

21. Order of the Ministry of Industry and Trade of the Russian Federation of May 5, 2014 No. 839 On Approval of the Strategy for the Development of the Ferrous Metallurgy of Russia for 2014-2020 and for the Prospect until 2030 and the Strategy for the Development of the Non-Ferrous Metallurgy of Russia for 2014-2020 and for the Prospect until 2030. Available online: https://www.garant.ru/products/ipo/prime/doc/70595824/ (accessed on 10 September 2020).

22. Litvinenko, V.S. Digital Economy as a Factor in the Technological Development of the Mineral Sector. Nat. Resour. Res. 2019, 28, 1-21. [CrossRef]

23. Yurak, V.; Dushin, A.; Mochalova, L. Vs sustainable development: scenarios for the future. J. Min. Inst. 2020, 242, 242. [CrossRef]

24. El-Deeb, A.B.; Brichkin, V.N.; Kurtenkov, R.V.; Bormotov, I.S. Extraction of Alumina from Kaolin: A Comparative Study of Pyrometallurgical and Hydrometallurgical Processes. Appl. Clay Sci. 2019, 172, 146-154. [CrossRef]

25. Nevskaya, M.A.; Marinina, O.A. Challenges and opportunities of state regulation of the innovation process in the Russian mineral resources sector. Acad. Strateg. Manag. J. 2017, 16, 149-159.

26. Elbendary, A.; Aleksandrova, T.; Nikolaeva, N. Influence of operating parameters on the flotation of the Khibiny Apatite-Nepheline Deposits. J. Mater. Res. Technol. 2019, 8, 5080-5090. [CrossRef]

27. Nevskaya, M.A.; Seleznev, S.G.; Masloboev, V.A.; Klyuchnikova, E.; Makarov, D.V. Environmental and Business Challenges Presented by Mining and Mineral Processing Waste in the Russian Federation. Minerals 2019, 9, 445. [CrossRef] 
28. Litvinenko, V.S.; Tsvetkov, P.S.; Molodtsov, K.V. The social and market mechanism of sustainable development of public companies in the mineral resource sector. Eurasian Min. 2020, 36-41. [CrossRef]

29. Kondrasheva, N.K.; Rudko, V.A.; Nazarenko, M.Y.; Povarov, V.G.; Derkunskii, I.O.; Konoplin, R.R.; Gabdulkhakov, R.R. Influence of Parameters of Delayed Coking Process and Subsequent Calculation on the Properties and Morphology of Petroleum Needle Coke from Decant Oil Mixture of West Siberian Oil. Energy Fuels 2019, 33, 6373-6379. [CrossRef]

30. Aleksandrova, T.N.; Heide, G.; Afanasova, A.V.; Academy, F.M.; Saint-Petersburg Mining University. Assessment of refractory gold-bearing ores based of interpretation of thermal analysis data. J. Min. Inst. 2019, 235, 30-37. [CrossRef]

31. Savchenkov, S.; Bazhin, V.; Brichkin, V.; Povarov, V.; Ugolkov, V.; Kasymova, D. Synthesis of magnesium-zinc-yttrium master alloy. Lett. Mater. 2019, 9, 339-343. [CrossRef]

32. Savchenkov, S.A.; Bazhin, V.Y.; Brichkin, V.N.; Kosov, Y.I.; Ugolkov, V.L. Production Features of Magnesium-Neodymium Master Alloy Synthesis. Mettalurgist 2019, 63, 394-402. [CrossRef]

Publisher's Note: MDPI stays neutral with regard to jurisdictional claims in published maps and institutional affiliations.

(C) 2020 by the authors. Licensee MDPI, Basel, Switzerland. This article is an open access article distributed under the terms and conditions of the Creative Commons Attribution (CC BY) license (http://creativecommons.org/licenses/by/4.0/). 